\section{PERBANDINGAN MODEL STRUKTUR MENGGUNAKAN METODE MATRIKS DENGAN PROGRAM SAP 2000}

\author{
Subaidillah Fansuri ${ }^{1, *}$, Dwi \\ Deshariyanto $^{2)}$ dan Anita Intan Nura \\ Diana $^{3)}$ \\ ${ }^{1}$ Program Studi Teknik Sipil Universitas \\ Wiraraja, subaidillah.sd@gmail.com \\ ${ }^{2}$ Program Studi Teknik Sipil Universitas \\ Wiraraja, ddeshariyanto@gmail.com \\ ${ }^{3}$ Program Studi Teknik Sipil Universitas \\ Wiraraja, anita@wiraraja.ac.id
}

\section{ABSTRAK}

Perkembangan teknologi di bidang teknik sipil semakin meningkat. Salah satu contohnya adalah penggunaan program komputer dalam analisis struktural. Dengan program ini, para insinyur sering menggunakan program lebih banyak dibandingkan dengan secara manual. Hal ini tentu saja menyebabkan penggunaan cara manual semakin ditinggalkan. Beberapa metode dapat digunakan dalam menganalisis struktur, baik metode manual maupun dengan menggunakan program komputer. Metode-metode ini memiliki jalur yang berbeda dalam menganalisis struktur. Berdasarkan perbedaan tersebut maka dilakukan analisis perbandingan antara metode manual (Metode Matriks) dan program komputer (Program SAP 2000) terkait dengan hasil perhitungan yang diperoleh dari masing-masing metode. Objek penelitian yang dianalisis adalah Model Struktural. Metode analisis yang digunakan adalah metode analisis komparatif. Analisis ini berkaitan dengan perbandingan dua metode yaitu Metode Matriks dan Program Sap 2000 terkait dengan hasil perhitungan gaya-gaya dalam yang akan dibandingkan besar dan selisihnya serta tingkat besaran yang dihasilkan. Hasil analisis menunjukkan bahwa nilai yang dihasilkan pada kedua metode analisis struktural tidak sama. Perbandingan hasil analisis struktur kedua metode pada masing-masing batang memiliki perbedaan nilai yang berbeda. Berdasarkan nilai frekuensi, masingmasing gaya dalam analisis struktur memiliki tingkat besaran yang berbedabeda. Pada semua model struktur masingmasing batang ada perbedaan besar dan ada perbedaan kecil.

\section{Kata Kunci : Model Struktural, Metode Matriks, SAP 2000, Perbandingan}

\section{ABSTRACT}

Technological developments in the field of civil engineering have been increasing. One example is the use of computer programs in structural analysis. With this program, engineers often use the program a lot compared to manually. This of course causes the use of manual methods to be increasingly abandoned. Several methods can be used in analyzing the structure, either manual method or by using a computer program. These methods have different paths in analyzing the structure. Based on these differences, a comparative analysis was carried out between the manual method (Matrix Method) and computer program (SAP 2000 Program) related to the calculation results obtained from each method. The object of study analyzed is the Structural Model. The analytical method used is the comparative analysis method. This analysis is related to the comparison of the two methods, namely the Matrix Method and the Sap 2000 Program related to the results of the calculation of the internal forces that will be compared the magnitude and difference and the level of the resulting magnitude. The results of the analysis show that the values generated in the two methods of structural analysis are not the same. Comparison of the results of the structural

Jurnal "MITSU" Media Informasi Teknik Sipil UNIJA Volume 9, No. 2, Oktober 2021 e-ISSN 2685-9173 
analysis of the two methods on each rod has a different value difference. Based on the frequency value, each force in the structural analysis has a different level of magnitude. In all structural models of each rod there is a large difference and there is a small difference.

Keyword : Structural Model, Matrix Method, SAP 2000, Comparison

\section{PENDAHULUAN}

Tahap awal pada perencanaan suatu struktur biasanya dimulai dengan perhitungan analisis struktur. Dalam menganalisis struktur baik statis tertentu maupun statis tidak tentu terdapat berbagai metode manual antara lain Matriks, Distribusi Momen (Hardy Cross), Takabeya dan beberapa metode manual lainnya. Dimana tujuan dari metode-metode tersebut tak lain hanya untuk mendapatkan besar gaya-gaya dalam, yaitu gaya yang bekerja didalam suatu konstruksi bangunan akibat adanya beban-beban yang terdapat pada struktur bangunan tersebut. Gaya-gaya dalam ini berupa momen, gaya lintang dan gaya geser. Menghitung besaran gaya-gaya dalam ini sangat penting sebagai langkah awal perencana dalam merencanakan sebuah bangunan. Karena apabila telah didapat nilai besaran gaya-gaya dalam, kita akan dapat merencanakan lebih lanjut seperti dimensi dari struktur dan tulangan bangunan tersebut sehingga dapat menahan beban-beban yang dipikulnya.

Perkembangan teknologi dibidang teknik sipil sudah semakin meningkat salah satu contoh yaitu penggunaan program komputer dalam analisis struktur. Beberapa program komputer telah tersedia sebagai alat penunjang dan mempermudah dalam perhitungan serta perencanaan sipil. Program komputer yang sering digunakan para perencana antara lain SAP2000, ETABS, dan aplikasi lainnya. Dengan adanya program ini, seringkali para engineer banyak menggunakan program tersebut dibandingkan dengan analisis secara manual. Hal ini tentunya menyebabkan penggunaan metode manual semakin lama semakin ditinggalkan.

Menganalisis struktur baik menggunakan metode manual ataupun menggunakan program komputer, tentu keduanya memiliki alur yang berbeda. Hasil perhitungan analisis struktur masingmasing metode (manual dan program) tentu memiliki nilai selisih yang beragam. Maka dari itu penulis ingin melakukan analisa perbandingan antara metode manual dengan program komputer. Dimana analisis tersebut akan membandingkan kedua metode perhitungan gaya-gaya dalam untuk mengetahui sejauh mana selisih nilai yang dihasilkan dari kedua metode.

Metode Matriks adalah suatu metode untuk menganalisa struktur dengan menggunakan bantuan matriks, yang terdiri dari : matriks kekakuan, matriks perpindahan, dan matriks gaya (Wahyuni, 2011).

Berdasarkan berbagai metode diatas, metode manual yang penulis akan analisis yaitu Metode Matriks. Penulis memilih metode matriks ini karena segala jenis bangunan dapat diketahui gaya-gaya dalamnya, baik struktur statis tertentu maupun struktur statis tidak tertentu.

Analisis struktur menggunakan program komputer yang akan penulis bandingkan dengan analisis struktur metode manual yaitu Program SAP2000. Program SAP2000 merupakan program yang dirancang untuk pengerjaan analisa struktur pada bidang teknik sipil, sesuai dengan fungsinya program SAP2000 dapat digunakan untuk menganalisa jenis struktur apapun dengan tampilan 2 dimensi maupun 3 dimensi. Keunggulan dari SAP2000.

Berdasarkan latar belakang, identifikasi dan cakupan masalah diatas maka rumusan masalah dari penelitian ini adalah "Bagaimana perbandingan hasil analisis perhitungan gaya-gaya dalam antara Metode Matriks dengan Metode 
menggunakan Program SAP2000 terkait nilai gaya-gaya dalam dan selisih nilai antar metode?"

Struktur merupakan sebuah sistem, artinya gabungan atau rangkaian dari berbagai macam elemen-elemen yang dirakit sedemikian rupa sehingga menjadi satu kesatuan yang utuh. Sedangkan model struktur merupakan macam-macam bentuk desain elemen struktur. Ada berbagai macam model struktur, tetapi model struktur yang akan dianalisis ada 5 (lima) yaitu struktur balok sederhana, struktur kantilever, struktur balok kantilever, struktur portal dan struktur rangka.

Balok sederhana (simple beam) adalah sebuah batang yang ditumpu pada kedua ujungnya masing-masing dengan sebuah sendi dan Akibat beban yang bekerja pada balok sederhana akan timbul reaksi tumpuan yaitu 2 reaksi pada tumpuan sendi dan 1 reaksi pada tumpuan rol. Berikut gambar struktur balok sederhana dimana pada ujung satunya merupakan sendi dan ujung satunya menggunakan rol.

Struktur kantilever adalah struktur dimana salah satu ujungnya dijepit dan ujung lainnya bebas yang batas kekuatannya adalah batas terbesar ukuran bangunan dimana perhitungan dan pemilihan material yang digunakan adalah meterial yang kaku.

Struktur Balok kantilever merupakan gabungan antara struktur balok dengan struktur kantilver. Dimana pada struktur balok terdapat dua penjepit tetapi salah satu atau kedua ujungnya menggantung.

Struktur Portal merupakan konstruksi bangunan petak dimana ujung-ujungnya bersifat kokoh dan kaku, sehingga dapat menahan gaya tekan, tarik, geser dan momen. Batang-batangnya terdiri atas balok dan kolom yang diperhitungkan untuk menahan gaya tekan, tarik dan momen. Gaya datar ke dalam portal yang dihasilkan pondasi mengakibatkan momen lengkung pada tiang, sehingga elemen portal menderita tekan dan momen lengkung karena beban q diatas balok dan momen lengkung mengadakan tarik dan geser pada material portal (Syaifuddin Zuhri, 2011).

Struktur rangka adalah struktur yang terdiri atas elemen-elemen linear, umumnya balok dan kolom yang saling berhubungan (Schodek,1998:362).

Struktur rangka merupakan susunan (rakitan) struktural dari semua jenis bagian struktur: bagian-bagian struktur dua-gaya, dan elemen-elemen struktur yang dibebani secara transversal seperti balok-balok dan elemen-elemen struktur yang dibebani secara transversal seperti balok-balok dan elemen-elemen struktur yang terbentuk tak teratur (Dishongh,2003:76).

Metode Matriks adalah suatu pemikiran baru pada analisa struktur, yang berkembang bersamaan dengan makin populernya penggunaan komputer otomatis untuk operasi-operasi perhitungan aritmatika (Supartono dan Teddy Boen, 1980).

Analisa struktur dengan metode matriks telah memberikan kemungkinankemungkinan bagi proses idealisasi ini. Seperti diketahui, suatu hal yang utama yang berhubungan dengan proses dari perencanaan struktur ialah menganalisa apa akibat dari pembebanan gaya-gaya pada konstruksi yang ditinjau. Tingkah laku dari konstruksi ini pada umumnya berhubungan sangat erat dengan perubahan stress dan strain yang terjadi padanya. Resultante stress ini bisa dalam bentuk gaya dalam, yaitu momen lentur, gaya lintang, gaya normal. momen torsi, sedangkan strain bisa menyatakan deformasi yang terjadi pada konstruksi.

Menganalisa perubahan bentuk ini, perhatian akan lebih baik dipusatkan pada lendutan linier atau anguler yang terjadi pada titik-titik diskrit ( titik-titik putus ) dari konstruksi. Dengan demikian yang perlu untuk dianalisa mula pertama ialah sifat dan tingkah laku dari elemen-elemennya bila dibebani oleh gaya-gaya. Di sini bisa 
didapatkan keuntungan bahwa hasil analisa satu elemen, dapat dipakai untuk elemenelemen lain yang sejenis. Kemudian digabungkan sifat-sifat dari elemen itu dalam satu model matematik dari konstruksi, dan menyatakannya dalam suatu kondisi yang tergabung, di mana dalam hal ini syarat kompatibiliti dari segi geometrik konstruksi harus sudah dipenuhi. Di samping itu, syarat kesetimbangan statis harus juga terpenuhi, baik dipandang dari segi seluruh konstruksi maupun untuk masing-masing elemen. Setiap elemen dari konstruksi harus berada dalam kesetimbangan sebagai akibat dari semua gaya yang bekerja padanya, baik itu bebanbeban luar atau gaya reaksi, maupun juga gaya-gaya yang datang dari elemen-elemen tetangganya. Bila proses ini sudah diselesaikan, maka tingkah laku dari konstruksi keseluruhan yang disebabkan oleh bekerjanya gaya-gaya luar akan bisa ditentukan.

Demikian dapat disimpulkan di sini, bahwa hal yang utama dalam analisa struktur untuk menentukan baik itu deformasi ataupun stress yang terjadi pada struktur, ialah sampai sejauh mana sudah diketahui sifat karakteristik hubungan gaya dan deformasi dari elemen-elemen struktur, dan memaksakan terpenuhinya semua syarat kompatibiliti dan kesetimbangan

Perlu kiranya ditambahkan disini, karena metode kekakuan ini analisanya dimulai dengan lendutan, kemudian mencari hubungan pada gaya-gaya yang timbul dititik-titik diskrit, maka akan sangat menguntungkan untuk memakai metode ini menganalisa suatu konstruksi dimana ketidak-tentuan kinematisnya (yang berhubungan erat dengan derajat kebebasan atau degree of freedom) adalah lebih kecil bila dibandingkan dengan ketidak tentuan statisnya. Dengan demikian, konstruksikonstruksi statis tak tentu yang sering dijumpai pada umumnya, akan lebih menguntungkan bila dianalisa dengan metode kekakuan ini, karena umumnya kontruksi-konstruksi ini mempunyai derajat ketidak tentuan statis yang besar.

Berhubung dengan hakekat dari metode kekakuan ini, maka analisa struktur akan selalu dimulai dengan memberikan pada struktur bersangkutan beberapa besaran "anu" yang dalam hal ini ialah merupakan lendutan pada titik diskrit sebagai besaran yang harus dicari.

Analisa akan dimulai dengan mengambil lendutan dititik-titik diskrit sebagai sasaran yang harus dihitung. Untuk mengetahui dimana harus "dipasang" besaran lendutan yang akan dicari tersebut, maka harus diketahui dahulu berapa derajat ketidak-tentuan kinematis atau derajat kebebasan (degree of freedom) dari struktur.

Derajat ketidak-tentuan kinematis ialah suatu besaran yang menyatakan jumlah komponen bebas dari lendutan dititik diskrit yang mungkin terjadi yang berhubungan dengan diberikannya suatu pembebanan pada struktur.

Tujuan dari penelitian ini adalah sebagai berikut :

1. Untuk mengetahui bagaimana hasil perhtungan gaya-gaya dalam analisis model struktur menggunakan Metode Matriks?

2. Untuk mengetahui bagaimana hasil analisis perhitungan gaya-gaya dalam model struktur menggunakan Program SAP2000?

3. Untuk Mengetahui bagaimana perbandingan antara hasil analisis perhitungan gaya-gaya model struktur menggunakan Metode Matriks dengan Program SAP2000?

\section{METODE PENELITIAN}

Penelitian ini merupakan jenis penelitian kuantitatif, dimana analisis yang dilakukan akan memaparkan selisih dan hasil perbandingan kedua metode analisis struktur secara kuantitatif berdasarkan perhitungan yang dilakukan. Berikut diagram alur analisa yang akan dilakukan : 


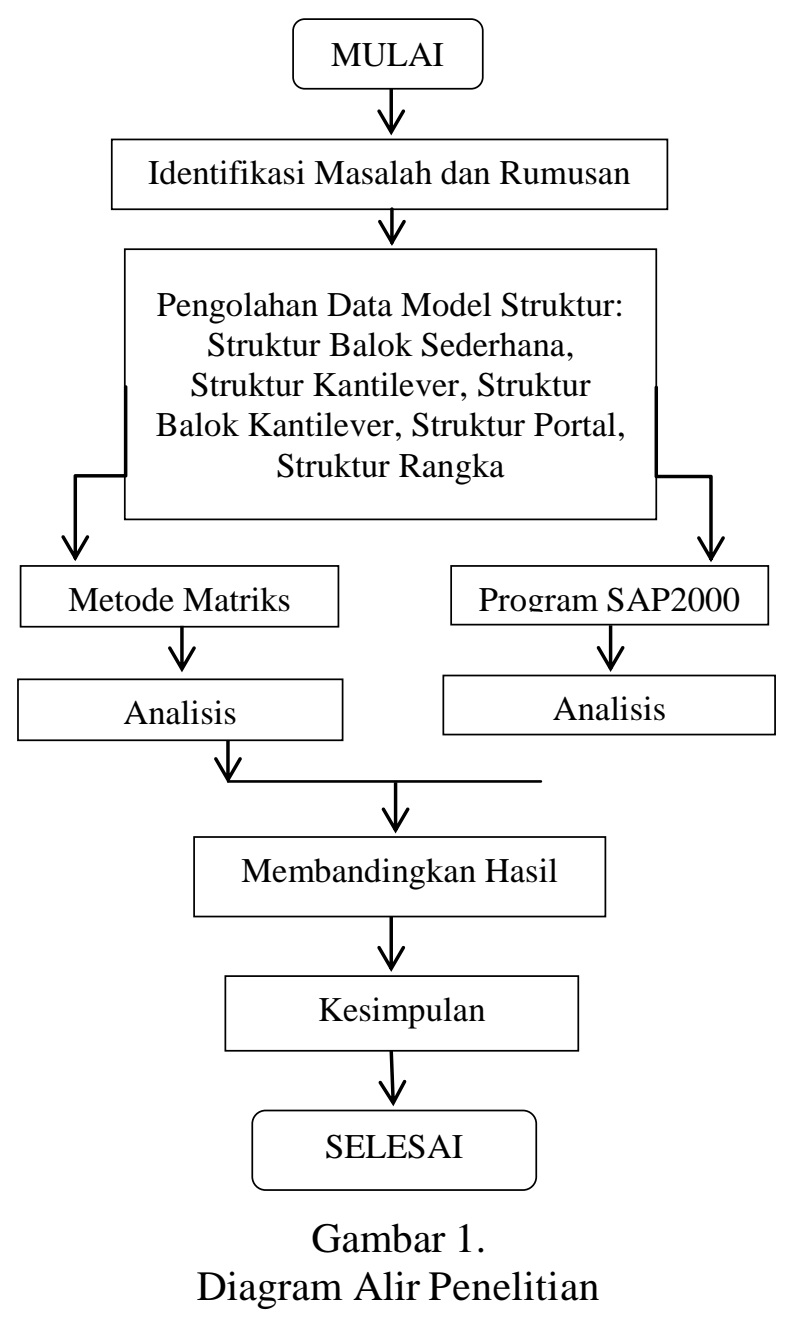

Ruang lingkup pada penelitian ini adalah perbandingan metode matriks dengan program SAP2000. Dimana objek dari perbandingan ini yaitu model struktur. Model struktur yang akan dianalisis antara lain struktur balok sederhana struktur kantilever, struktur balok kantilever, struktur portal dan struktur rangka. Pemilihan objek yang dianalisis tersebut dikarenakan model struktur merupakan langkah awal untuk mengalisis struktur.

Metode analisa data yang digunakan adalah metode perbandingan. Analisa ini difokuskan pada perbandingan kedua metode (Matriks dan Program SAP2000) terkait hasil perhitungan-perhitungan gayagaya dalam yang dilakukan.

Data yang telah diasumsikan kemudian dilakukan perhitungan- perhitungan gaya-gaya dalam pada kelima model struktur yaang mewakili objek dengan menggunakan metode manual yaitu metode matriks. Kemudian dilakukan perhitungan dengan menggunakan program komputer yaitu SAP2000 V14. Perbandingan yang dilakukan tersebut nantinya akan dihitung besar dan selisih gaya-gaya dalam yang timbul dari masingmasing perhitungan.

\section{HASIL DAN PEMBAHASAN}

\subsection{Analisis Struktur Balok Metode Matriks dengan Program SAP 2000}
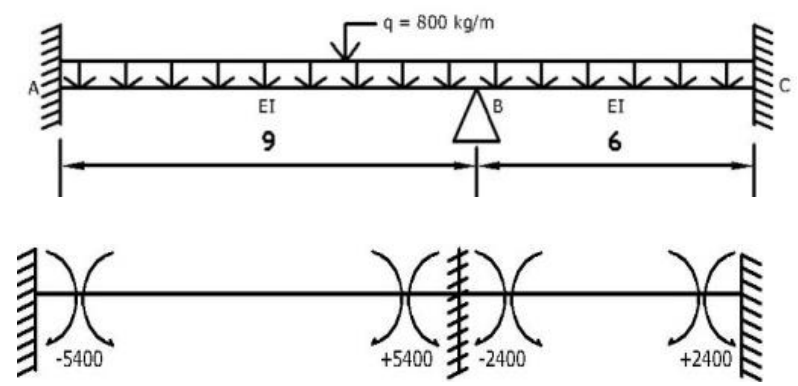

Gambar 2.

Momen Primer Matriks

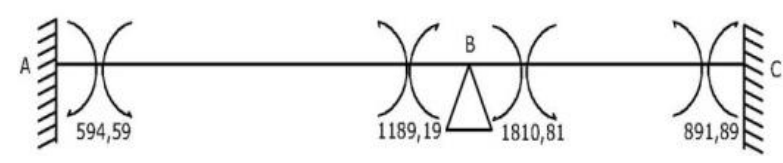

Gambar 3.

Hasil Distribusi Gaya Dalam Metode Matriks

Adapun hasil analisa struktur balok menggunakan SAP2000 :

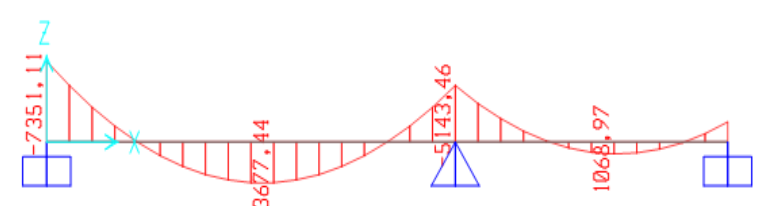

Gambar 4.

Hasil Momen SAP 2000

Analisis Balok diatas didapat selisih dari kedua metode yaitu sebagai berikut : 
Tabel 1.

Perbandingan hasil perhitungan matriks dan SAP 2000 pada balok struktur

\begin{tabular}{|c|c|c|r|}
\hline Reaksi & Matriks & SAP2000 & Selisih \\
\hline M-A & +5994.59 & +735.11 & 1356.52 \\
\hline M-BA & -4210.81 & -3677.44 & 533.37 \\
\hline M-BC & +4210.19 & +5143.46 & 933.27 \\
\hline M-C & -1508.11 & -1068.97 & 439.14 \\
\hline
\end{tabular}

Berikut grafik perbandingan antara kedua metode pada analisa struktur balok :

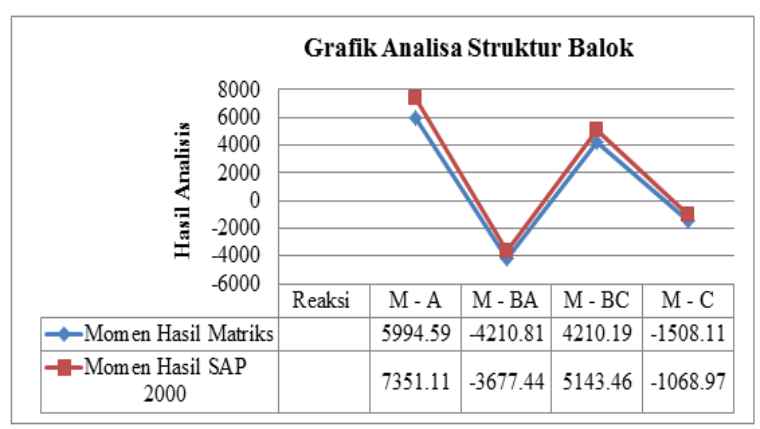

Gambar 5.

Grafik Analisa Struktur Balok

\subsection{Analisis Struktur Kantilever Metode Matriks dengan Program SAP2000}

Berikut hasil analisa struktur kantilever menggunakan metode matriks :

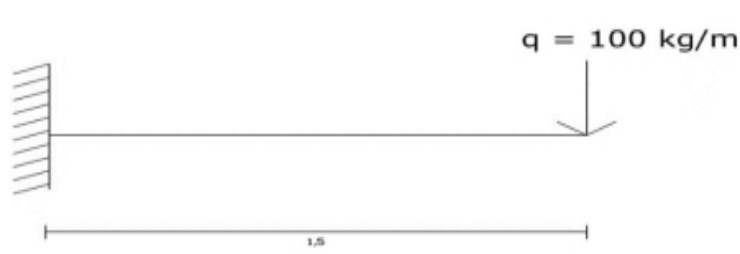

Gambar 6.

Struktur Kantilever yang Dianalisis

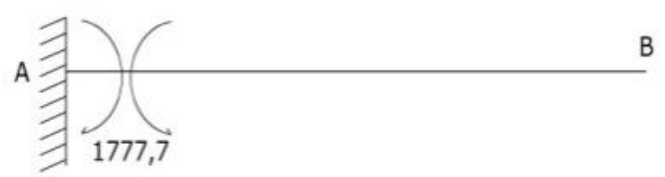

Gambar 7.

Hasil Distribusi Gaya dalam Metode Matriks

Adapun hasil analisa struktur kantilever menggunakan SAP2000 yaitu :

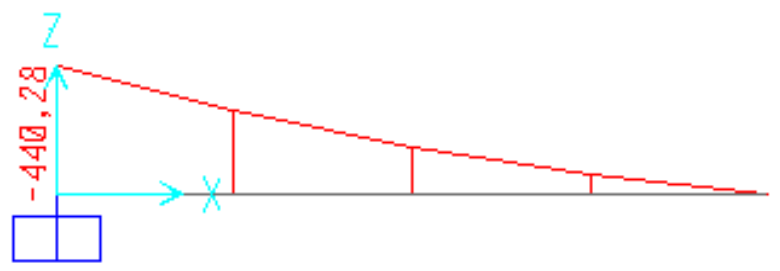

Gambar 8.

Hasil Momen SAP 2000

Analisis Kantilever diatas didapat selisih dari kedua metode yaitu sebagai berikut :

Tabel 2.

Hasil analisis kantililever

\begin{tabular}{|c|c|c|c|}
\hline Reaksi & MAtriks & SAP2000 & Selisih \\
\hline M-A & -1777.7 & -440.28 & -1337.79 \\
\hline
\end{tabular}

\subsection{Analisis Struktur Kantilever Metode Matriks dengan Program SAP2000}

Berikut hasil analisa struktur balokkantilever menggunakan metode matriks yaitu :

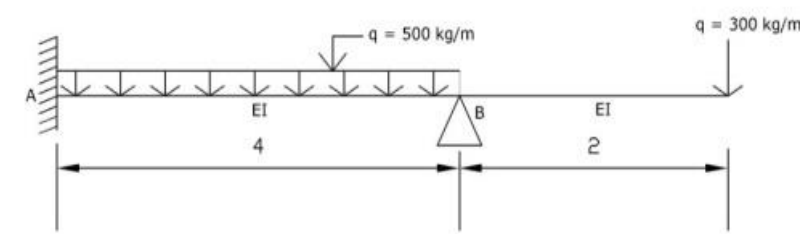

Gambar 9.

Balok Kantilever yang Dianalisis

Maka didapat gaya dalam dari metode matriks :

$$
\begin{aligned}
\text { MA } & =+444.45 \mathrm{~kg} \cdot \mathrm{m} \mathrm{MBA} \\
& =-1111.12 \mathrm{~kg} \cdot \mathrm{m} \mathrm{MBC} \\
& =-822.22 \mathrm{~kg} \cdot \mathrm{m}
\end{aligned}
$$

Adapun hasil analisa struktur balok kantilever menggunakan SAP2000 yaitu :

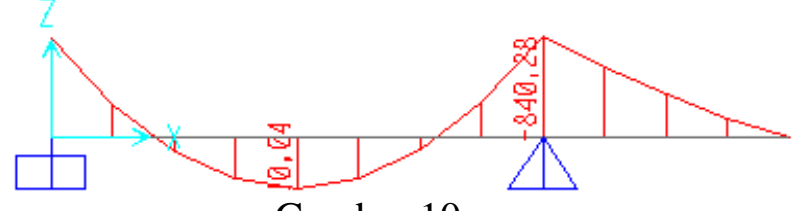

Gambar 10.

Hasil Momen SAP2000 
Struktur dimodelkan dengan elemen frame biasa dengan dimensi dan material sesuai dengan yang direncanakan dalam gambar rencana.

Analisis Balok Kantilever diatas didapat selisih dari kedua metode yaitu sebagai berikut

Tabel 3.

Hasil selisih analisis kantililever

\begin{tabular}{|c|c|c|c|}
\hline Reaksi & Matriks & SAP2000 & Selisih \\
\hline M-A & +444.45 & +820.19 & 375.74 \\
\hline M-BA & +1111.12 & +410.04 & 701.08 \\
\hline M-BC & -822.22 & -840.28 & 18.06 \\
\hline
\end{tabular}

Berikut grafik perbandingan antara kedua metode pada analisa struktur balok kantilever :

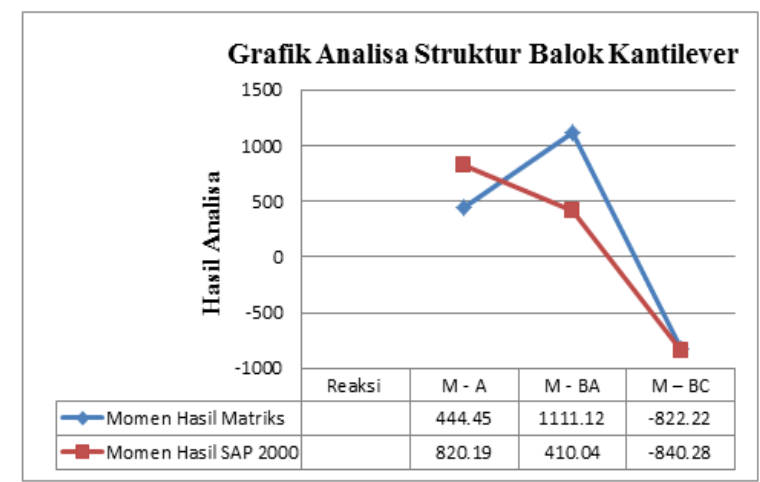

Gambar 11.

Grafik Analisa Struktur Balok Kantilever

\subsection{Analisis Struktur Portal Metode} Matriks dengan Program SAP2000

Berikut hasil analisa struktur portal menggunakan metode matriks yaitu:

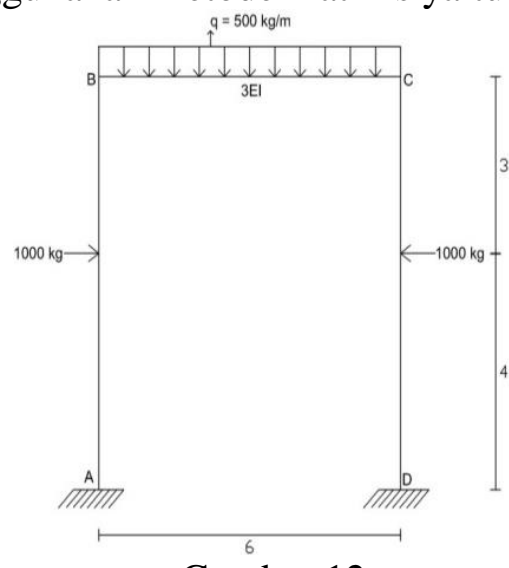

Gambar 12.

Struktur Portal yang Dianalisis

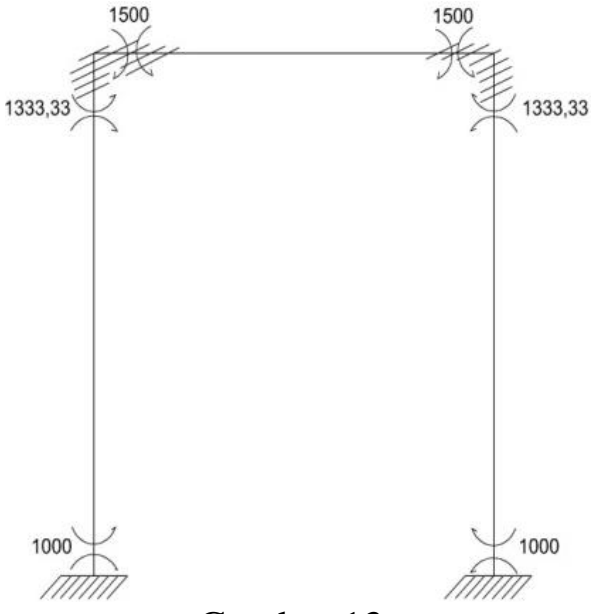

Gambar 13.

Momen Primer Matriks

Maka didapat gaya dalam dari metode matriks :

MA $=966.61 \mathrm{~kg} \cdot \mathrm{m}$

MBA $=-1400.11 \mathrm{~kg} \cdot \mathrm{m}$

$\mathrm{MBC}=1399.38 \mathrm{~kg} . \mathrm{m}$

$\mathrm{MCB}=-1399.83 \mathrm{~kg} \cdot \mathrm{m}$

$\mathrm{MCD}=1400.11 \mathrm{~kg} \cdot \mathrm{m}$

$\mathrm{MD}=-966.61 \mathrm{~kg} \cdot \mathrm{m}$

Adapun hasil analisa struktur portal menggunakan SAP2000 yaitu :

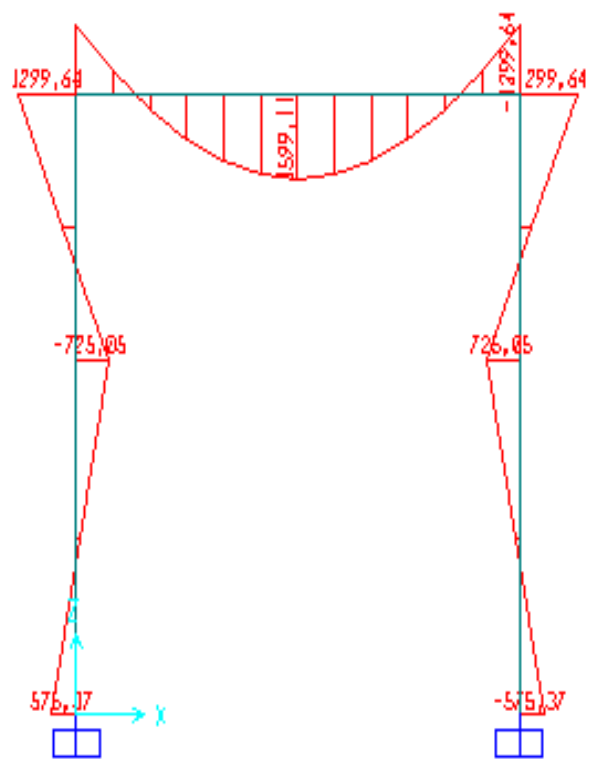

Gambar 14.

Hasil Momen SAP2000 
Analisis Struktur Portal diatas didapat Selisih dari kedua metode yaitu sebagai berikut :

Tabel 4.

Hasil selisih analisis struktur portal

\begin{tabular}{|c|c|c|c|}
\hline Reaksi & Matriks & SAP 2000 & Selisih \\
\hline M-A & +966.61 & +575.37 & 391.24 \\
\hline M-BA & -1400.11 & -725.05 & 675.06 \\
\hline M-BC & +1399.83 & +1299.64 & 100.19 \\
\hline M-CB & -1399.83 & -1299.64 & 100.19 \\
\hline M-CD & +1400.11 & +725.05 & 675.06 \\
\hline M-D & -966.61 & -575.37 & 391.24 \\
\hline
\end{tabular}

Berikut grafik perbandingan antara kedua metode pada analisa struktur portal yang terjadi :

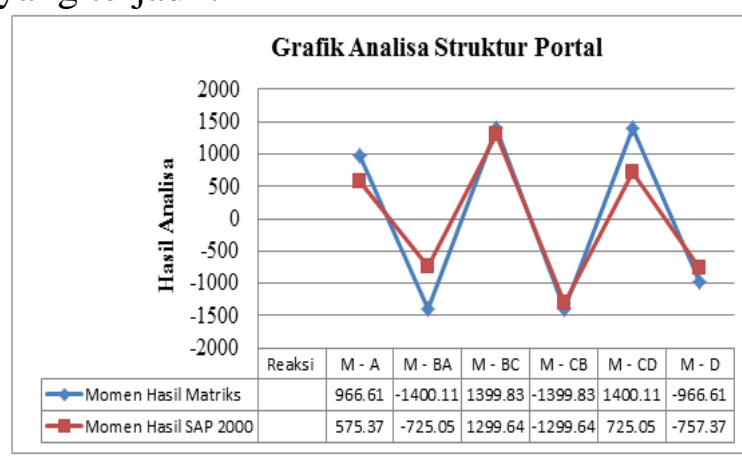

Gambar 15.

Grafik Analisis Dua Metode pada Struktur Portal

\subsection{Analisis Struktur Rangka Metode Matriks dengan Program SAP2000}

Pada analisa konstruksi rangka batang ini justru hanya mengalami deformasi normal (axial) saja. Proses analisa ini hanya berbeda pada cara memberikan vektor lendutan dimana hanya ada vektor lendutan translasi saja. Dan pada matriks $\mathrm{S}$ yang menyatakan hubungan gaya dalam dan deformasi, baik gaya dalam maupun deformasi yang timbul hanya bersifat axial saja. Berikut hasil analisa struktur rangka menggunakan metode matriks yaitu :

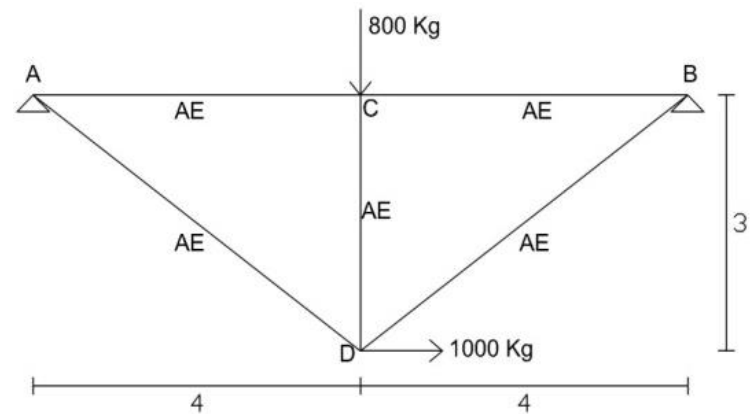

Gambar 16.

Rangka Batang yang Dianalisa

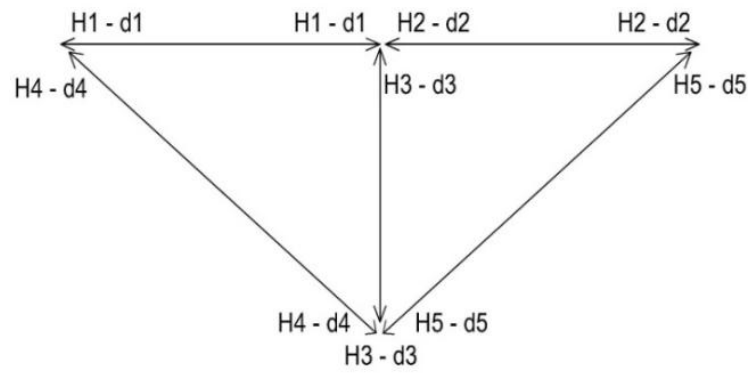

Gambar 17.

Diagram H-d

Dengan memperhatikan gambargambar diatas dengan mudah dapat ditentukan matriks (A), yaitu matriks yang menyatakan hubungan deformasi dan lendutan.

Sesuai yang telah dijelaskan diatas, maka elemen-elemen pada konstruksi rangka batang ini hanya menderita deformasi axial saja. Dengan demikian hanya menimbulkan gaya dalam normal saja. Maka didapat gaya batang yang dihasilkan dari metode matriks yaitu :
$\mathrm{H} 1=0$
$\mathrm{H} 2=0$
$\mathrm{H} 3=-533.33$
$\mathrm{H} 4=893.16$
$\mathrm{H} 5=-356.85$ 


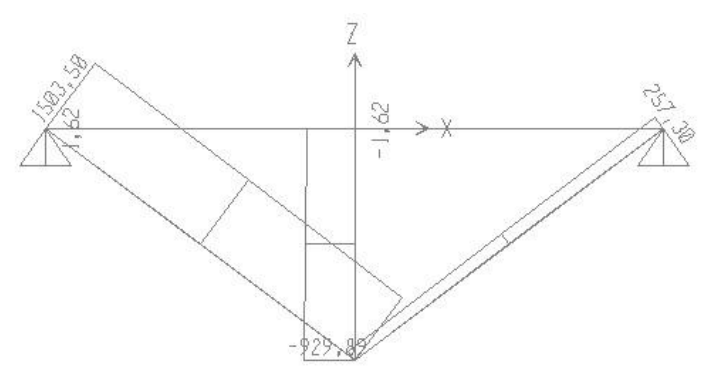

Gambar 18.

Hasil Gaya Normal SAP2000

Maka elemen-elemen pada konstruksi rangka batang ini hanya menderita deformasi axial saja. Dengan demikian hanya menimbulkan gaya dalam normal saja. Karena disini membahas konstruksi yang elastis, maka hukum Hooke berlaku karenanya.

Analisis Struktur Rangka diatas didapat perbandingan dari kedua metode yaitu sebagai berikut :

Tabel 5.

Hasil selisih analisis struktur rangka

\begin{tabular}{|c|c|c|c|}
\hline Reaksi & Matriks & SAP2000 & Selisih \\
\hline H1 & 0 & -1.62 & 1.62 \\
\hline H2 & 0 & -1.62 & 1.62 \\
\hline H3 & -533.33 & -929.89 & 396.56 \\
\hline H4 & +893.16 & +1503.50 & 610.34 \\
\hline H5 & +356.85 & +257.30 & 99.55 \\
\hline
\end{tabular}

Berikut grafik perbandingan antara kedua metode pada analisa struktur rangka:

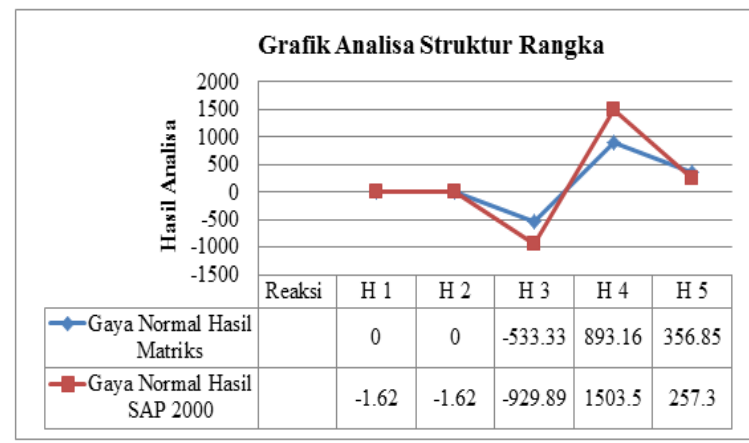

Gambar 19.

Grafik Analisa Struktur Rangka

Adapun hasil dari setiap perhitungan yang didapat diantaranya adalah :

a. Hasil perbandingan balok struktur menggunakan metode matriks dan
SAP2000 yaitu analisis kedua metode pada balok struktur didapat selisih yang cukup tinggi.

b. Perbandingan struktur kantilever menggunakan metode matriks dan SAP2000 yaitu analisis kedua metode pada struktur kantilever didapat selisih yang cukup tinggi.

c. Perbandingan struktur balok kantilever menggunakan metode matriks dan SAP2000 yaitu analisis kedua metode pada struktur balok kantilever pada setiap batang ada yang selisihnya rendah dan ada yang selisihnya tinggi.

d. Perbandingan struktur portal menggunakan metode matriks dan SAP2000 yaitu analisis kedua metode pada struktur portal pada setiap batang ada yang selisihnya rendah dan ada yang selisihnya tinggi.

e. Perbandingan struktur rangka menggunakan metode matriks dan SAP2000 yaitu analisis kedua metode pada struktur rangka pada setiap batang ada yang selisihnya rendah dan ada yang selisihnya tinggi.

\section{KESIMPULAN}

Berdasarkan dari hasil penelitian dan hasil pembahasan yaitu analisis struktur terhadap model-model struktur antara metode matriks dengan program SAP2000 memiliki analisis yang berbeda sehingga nilai yang dihasilkan pada kedua metode tidak sama. Perhitungan selisih hasil analisis struktur kedua metode pada setiap batang memiliki nilai hasil yang beragam. Besar selisih antara kedua metode pada setiap batang ada yang memiliki nilai cukup tinggi dan ada yang memiliki nilai cukup rendah.

\section{DAFTAR PUSTAKA (TNR 12)}

Dewobroto, Wiryanto., (2007), Komputer Rekayasa Struktur dengan SAP 2000. PT. Alex Media Komputindo, Jakarta. 
Nasution, Amrinsyah., (2009), Metode Matriks Kekakuan Analisis Struktur. Institut Bandung, Bandung.

Suhendro, Bambang., (2005), Analisis Struktur Metode Matrix. Jurusan Teknik Sipil, Fakultas Teknik, Universitas Gajah Mada, Yogyakarta.

Supartono, dan Teddy Boen., (1980), Analisa Struktur dengan Metode Matrix. Fakultas Teknik, Universitas Indonesia, Jakarta.

Susastrawan., (1991), Analisa Struktur dengan Cara Matriks. Penerbit ANDI OFFSET, Jogyakarta.

Zacoeb, Achfas., (2014), Konsep Dasar Analisis Stuktur. Jurusan Teknik Sipil, Fakultas Teknik, Universitas Brawijaya, Malang. 